Health service provision and the use of pressure redistributing devices: Mixed methods study of community dwelling individuals with pressure injuries

Debra JACKSON RN PhD ${ }^{1,2,3}$, Lisa DURRANT $\mathrm{PhD}^{1,2}$, Emily BISHOP RN ${ }^{4}$, Helen WALTHALL RN $\mathrm{PhD}^{1}$, Ria BETTERIDGE RN, MSc ${ }^{2}$, Sarah GARDNER RN, MSc ${ }^{4}$, Wendy COULTON ${ }^{1}$, Marie HUTCHINSON RN, $\mathrm{PhD}^{5}$, Stephen NEVILLE RN PhD ${ }^{6}$, Patricia M DAVIDSON RN, $\mathrm{PhD}^{7}$, Kim USHER RN PhD ${ }^{8}$

djackson@brookes.ac.uk (corresponding author).

${ }^{1}$ Oxford Institute for Nursing, Midwifery \& Allied Health Research (OxINMAHR), The Colonnade, Oxford Brookes University, Oxford, UK.

${ }^{2}$ Oxford University Hospitals NHS Foundation Trust, Oxford, UK.

${ }^{3}$ University of Technology, Sydney, Australia.

${ }^{4}$ Oxford Health NHS Foundation Trust, Oxford, UK.

${ }^{5}$ Southern Cross University, Lismore, Australia.

${ }^{6}$ Auckland University of Technology, Auckland, New Zealand.

${ }^{7}$ Johns Hopkins University, Baltimore, USA.

${ }^{8}$ University of New England, Australia.

Funding: This work was supported by Oxford Brookes University central research fund.

Conflict of Interest: The authors declare that they have no conflict of interest. 


\title{
Health service provision and the use of pressure redistributing devices: Mixed methods study of community dwelling individuals with pressure injuries
}

\begin{abstract}
Background: Attention to patient safety and harm has largely focused upon hospital-based care. Care provided in the home setting is a vital component of pressure injury prevention and management, and is a growing component of health care systems.
\end{abstract}

Objectives: The aim of this paper is to describe the use of health services and pressure relieving / redistributing equipment in community dwelling patients with pressure injuries.

Design: A mixed-methods collective case study, located in a defined, diverse geographic postcode area in the United Kingdom.

Methods: Quantitative retrospective review of electronic and paper medical records of adult pressure injury patients identified from 2015 district nursing records. Qualitative semistructured interviews of adult patients, with the capacity to consent, who were receiving, or received treatment for a pressure injury in 2016 whilst being resident in their own homes.

Results: 103 mandatory reports of individual community based patients with pressure injury (PI) in the study catchment area in 2015 formed the quantitative dataset, and revealed 90 patients were offered a variety of pressure redistributing devices and equipment but only $1 / 3$ of patients used the equipment as recommended. Qualitative interviews of 12 patients in 
2016, reported according to COREQ guidelines, revealed two major themes in relation to service use; firstly patients felt they had become reliant on the care provided by community health services, and secondly patients were concerned about the consistency and continuity of their care during transition periods between healthcare providers.

Conclusions: There is a need for authentic patient involvement and education particularly during periods of service change and care transition. Interventions that are acceptable to patients and can be incorporated in self-care strategies, including ongoing individualised assessment around the use of PI-associated equipment are needed.

Impact Statement: Community pressure injury treatments are time and equipment intensive, lack of ongoing assessment renders equipment unused and leaves patients vulnerable.

Keywords: Pressure injury, pressure ulcer, community care, mixed methods research, patient experience, patient voice, pressure redistributing equipment, pressure relieving equipment.

Funding: This work was supported by XXXX University central research fund.

Conflict of Interest: The authors declare that they have no conflict of interest. 


\section{Background}

PI prevalence remains unacceptably high and generates significant human and economic costs. Dealey et al., (2012) estimated UK costs from $£ 1214$ to $£ 14108$ per ulcer depending on severity, resulting in an overall daily spend of $£ 3.8$ million (NHS Stop the Pressure, 2016).

The impact of PI on quality of life including the ability to function in all areas of physical and psychological health is acknowledged in the literature (Gorecki et al., 2009; Jackson et al., 2016). A number of factors are known to increase a person's susceptibility to developing a PI including serious illness, a neurological impairment, immobility, malnutrition (Coleman et al., 2013), being older with multiple co-morbidities (Landi et al., 2007), symptoms such as shortness of breath and urinary problems (Skogestad et al., 2017), and being recently discharged from hospital (Asimus \& Li, 2011).

Attention to patient safety and harm has largely focused upon hospital care (Hughes, 2008). Consequently, the evidence for PI prevention and management is almost entirely derived from hospital-based or nursing home studies (Johansen et al., 2015). Yet, care provided in the home setting is a vital component of PI prevention and management, and is a growing component of health care systems. Guest et al. (2016) calculated that two-thirds of UK wound care expenditure is incurred in the community setting, with PI patients requiring 1.6 million community nurse visits annually, costing in excess of $£ 88$ million. A significant number of patients developed PI whilst in community-based care (Moore \& Cowman, 2012), and Worsley et al. (2016) found $81 \%$ of patients $(n=1026)$ admitted to hospital with a community-acquired PI came from their own homes, rather than formal care settings. The transferability of principles and evidence for PI prevention derived from hospital settings is likely to have questionable efficacy in community health care (Vincent \& Amalberti, 2016). 
It is important to develop a deeper understanding of patient experiences of PI care in their homes.

Common community-based care strategies include the provision of pressure redistributing devices and equipment, which are often used in conjunction with other skin care strategies. Some evidence suggests that patients may not consistently use the pressure-relieving equipment provided or follow pressure-relieving protocols (Heale, 2016), and that prevention strategies initiated by nurses may be implemented in a haphazard and erratic manner (Moore \& Price, 2004). In order to facilitate full patient engagement and participation, research is needed to identify the perceptions of patients with PI into the services they are receiving and how they perceive the care that is delivered to them. Therefore, it is important to develop more insight into patients experience, models and approaches to inform harm mitigation and PI recovery in the home environment.

This paper is drawn from a larger, detailed case study that explored PI occurrence, patient demographics, care characteristics and the experience of living with a PI (Jackson et al., 2017). In this component of the study, we were particularly interested in examining patients' use of community health services and PI associated pressure redistributing equipment.

\section{Study Methods}

Setting: A mixed-methods case study review of a single UK postcode district provided a detailed report of PI occurrence, demographics and patient characteristics within that bounded location. The case study used both quantitative and qualitative sources of evidence (Yin, 1984) to gain a numerical insight into the scale of community service provision for PI, enriched by the patient voice to offer insight into the personal experience of living with a PI. 
The community at the focus of the case study consisted of a population of approximately 50,000 adults, of which around 3100 were aged over 75 years (ONS census, 2011). To ensure this work reflected needs and priorities of PI patients, a person with lived experience of PI accepted an invitation to be part of the research team (XX). This team member provided input at all stages of the study, and was not recruited as a participant into the study.

Quantitative dataset: The case study review generated a retrospective database of community NHS patients over a 12 month period in 2015. Data were collated from March to October 2016 by a single member of the community based nursing team with no contact or caring responsibilities for any of the patients in the case study region. The data for the numeric component of the study was drawn from mandatory reports of PI in a community NHS service supplemented with data from electronic and paper medical records to generate an anonymous dataset where patients were assigned a unique individual code. Due to diversity of terms in written records, data on PI equipment was categorised simply as cushions, pressure redistributing mattresses (including overlays and dynamic air mattresses), and boots (including heel off-loading devices and inflatable bootees). Nursing records were also audited to verify PI equipment and devices were used as recommended. The data was analysed descriptively using SPSS v22.0 (IBM Analytics).

Qualitative interviews: For the qualitative component of the study, narratives were collected from patients who had experience of living with PI in the community in 2016. Direct care teams, comprising hospital and community tissue viability nurses, district nurses and hospital or community podiatrists, identified potential participants from current patient caseloads according to the inclusion criteria. 
Inclusion criteria for participation in qualitative interviews: In order to be eligible for inclusion, patients were required to be: aged 18 years or over; currently receiving or just completed treatment for a PI within 2016; assessed by their care provider as having adequate capacity to provide informed consent; residing within the defined, bounded case study area; and able to complete a conversational style interview in any language.

Exclusion criteria: Patients receiving end-of-life care or deemed by their care teams to lack the capacity to understand and provide informed consent were excluded from the study.

Recruitment of patients for interview was achieved over a 23 week period (May- October 2016). During a face-to-face routine appointment, direct care teams offered potential participants a study pack, consisting of an information sheet and invitation to participate, to read and discuss with their care providers or families. No further prompts or reminders were sent. Patients wishing to participate then contacted the research team directly to volunteer to take part in a qualitative interview. All patients were given written and oral information about the study, including confidentiality and withdrawal, to ensure informed consent. Family carers present at the interview were also invited to consent and participate in accordance with the patient's wishes. Interviews were all conducted in English, a translation service was available for participants without English, but none of the participants required this service. Patients and family members/carers were interviewed at a location of their choice. Storied accounts of living with a PI were gathered, facilitated by the same experienced female health professional (XX) who had no prior contact with the participants. Immediately prior to the interview the participant, aided by the interviewer, completed a short questionnaire (EQ-5D ${ }^{\circledR}$ with permission from EuroQol Research Foundation) to both build rapport and highlight any domains from mobility, self-care, usual activities, pain and discomfort, or depression and anxiety likely to form the main themes in the interview. Conversational style interviews, 
informed by a general topic guide devised by a panel of experts, including a patient with PI experience, lasted on average 37 minutes (range 16 to 69 minutes). Interviews were audiorecorded and transcribed verbatim. Transcripts were analysed using a thematic approach (Borbasi \& Jackson 2012), focussing on the quality and richness of data to identify themes. The study is grounded in hermeneutic phenomenology, both descriptive (phenomenological) as participants were able to speak for themselves, and interpretive (hermeneutic) as the facts of the lived experience need to be captured in language which is inevitably an interpretive process (Smith et al., 2009). Data were analysed by three of the research team (XX, XX, $\mathrm{XX}$ ) and recruitment ceased when agreement was reached that no new themes were emerging (Fusch \& Ness, 2015). No participants requested to review their transcribed interview, but all participants requested a summary of results at the conclusion of the study.

Ethical procedures and funding: Full ethical approvals from the National Ethical Research Committee, NHS and the sponsoring University were gained prior to study commencement. The study was funded by XXX central research fund.

\section{Findings}

Quantitative dataset findings: For the 2015 calendar year, there were 103 individual community based patients with PI in the study catchment area. Documents showed that patients were offered a variety of pressure redistributing devices and equipment: 90/103 $(87 \%)$ had equipment provided by the community NHS Trust; $4(4 \%)$ did not require any equipment; 2 (2\%) refused all equipment; and 7 (7\%) files had no relevant documentation. Breakdown, by type, of the equipment provided revealed the majority of patients had a pressure redistributing cushion and mattress (see Figure 1). 
Figure 1: Pattern of equipment utilisation for community dwelling patients $(n=90)$ with PI

$\mathbf{x}$-axis $=$ number of patients.

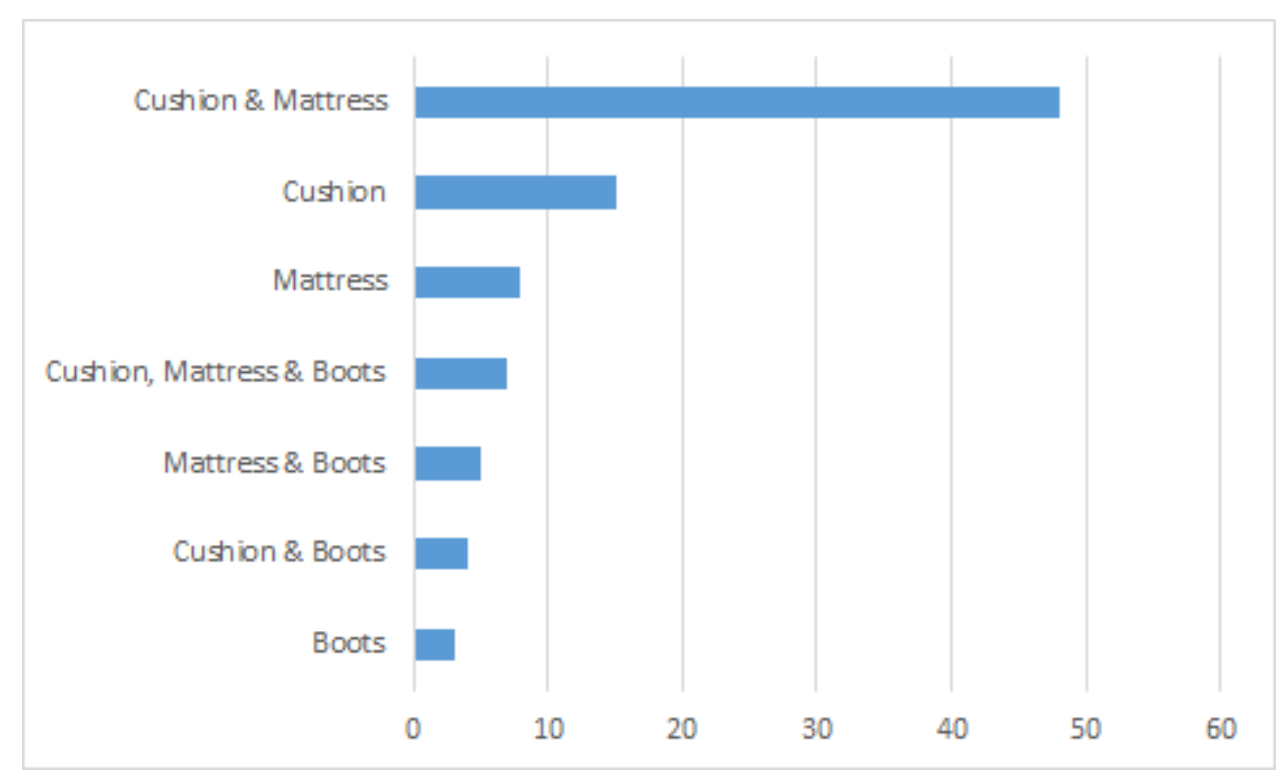

Of the 90 community patients utilising PI equipment: only 28/90 patients (31\%) were using the equipment as recommended; 36/90 (40\%) were recorded as partially using the equipment as recommended; 6/90 (7\%) were recorded as not using the equipment as recommended; and 20/90 (22\%) did not have details on equipment use recorded. Examples of equipment misuse included removal of overlay mattresses from beds, placing an additional covering over pressure redistributing cushions and removal of heel off-loading devices. Not all equipment offered to patients was accepted. The item most likely to be refused was the mattress (9 patients), followed by boots ( 5 patients) and the cushion ( 3 patients), although the reasons for refusing equipment were not recorded in the case study database. 
Qualitative interview findings: Eligible patients were identified by their direct care teams to receive study information. Of 32 patients identified, 12 consented to the study and were interviewed within a private hospital room ( 3 patients) or at home ( 9 patients); 5 patients opted to have family members/carer's present, who also contributed to the interview.

Evaluation of factors contributing to non-participation was not possible due to the voluntary nature of study recruitment. Analysis of demographics of the interviewed participants confirmed a diverse interview sample was achieved (see table 1).

Table 1: Characteristics of interview participants

\begin{tabular}{|c|c|c|c|}
\hline Participant & Gender/age & $\begin{array}{l}\text { Site / (EPUAP } \\
\text { category) }\end{array}$ & Duration of PI \\
\hline 1 & \multirow[t]{2}{*}{$\mathrm{f} / 75$} & \multirow[t]{2}{*}{ Toes (2) } & \multirow{2}{*}{$\begin{array}{l}\text { Longer than } 1 \text { year, damage occurring at } \\
\text { different sites on both feet }\end{array}$} \\
\hline $\begin{array}{l}\text { 1a carer of } \\
\text { participant } 1\end{array}$ & & & \\
\hline 2 & \multirow[t]{2}{*}{$f / 31$} & \multirow[t]{2}{*}{ Feet (4) } & \multirow{2}{*}{$\begin{array}{l}\text { Over } 20 \text { years continuously affected with PU's } \\
\text { at different sites on both feet }\end{array}$} \\
\hline $\begin{array}{l}\text { 2a carer of } \\
\text { participant } 2\end{array}$ & & & \\
\hline 3 & \multirow[t]{2}{*}{$\mathrm{m} / 75$} & \multirow[t]{2}{*}{ Heels (2) } & \multirow[t]{2}{*}{12 years damage recurring at same site } \\
\hline $\begin{array}{l}\text { 3a carer of } \\
\text { participant } 3\end{array}$ & & & \\
\hline 4 & $\mathrm{f} / 92$ & Heel (4) & 8 months not healed \\
\hline 5 & $\mathrm{~m} / 62$ & Heel (2) & 6 years not healed \\
\hline 6 & $\mathrm{~m} / 83$ & Heel (4) & 6 months healed \\
\hline 7 & \multirow[t]{3}{*}{$f / 86$} & \multirow[t]{3}{*}{ Sacrum (4) } & \multirow[t]{3}{*}{6 years not healed } \\
\hline $\begin{array}{l}\text { 7a carer of } \\
\text { participant } 7\end{array}$ & & & \\
\hline $\begin{array}{l}7 \mathrm{~b} \text { carer of } \\
\text { participant } 7\end{array}$ & & & \\
\hline 8 & $\mathrm{f} / 52$ & Toe (2) & 10 years recurring damage at same site \\
\hline 9 & $\mathrm{f} / 57$ & Coccyx (3) & 3 years not healed \\
\hline 10 & $\mathrm{f} / 76$ & Sacrum ( 3) & 14 months healed but on prophylactic dressing \\
\hline 11 & $\mathrm{f} / 80$ & Heel (4) & 2 months not healed \\
\hline 12 & $f / 80$ & Buttock (4) & 3 months not healed \\
\hline
\end{tabular}


Nine of the 12 (75\%) interviewed participants recounted being provided with PI equipment (See Table 2). In accordance with the quantitative data, inconsistent or inappropriate use of this equipment was a common theme in the interview narratives. Five of the $12(42 \%)$ participants used the equipment provided as recommended, three (25\%) only partially used equipment as recommended, one (8\%) participant refused all equipment offered and three (25\%) participants had no equipment provided. This poor level of uptake, due to discomfort or unsuitability of many aids to the home setting, was illuminated by the narratives of the participants. One patient, provided with boots to wear at night, found they "kept falling off in bed" (participant 4). Similarly another recollected being supplied with boots but stated "Oh yeah, I had those once. I don't want those. No I can't be bothered with this" (participant 10).

Discomfort from equipment was exacerbated for patients in their own homes when assistance was not readily available. Participant 10 reported difficulties and discomfort using a dynamic air mattress, and had to recruit help from her daughter to take action to prevent it from pinching her skin stating "What my daughter done, she put a blanket under the sheets so it's a bit softer to lay on" (participant 10).

The provision of equipment being mismatched to patients needs or lifestyles was exemplified by the striking account of participant 6 , having entirely removed the mattress cover from his bed stating "I don't think much of it" (participant 6) and preferring to sleep in his own rising recliner chair using the supplied pressure redistributing cushion although he choose to cover it with a towel to enhance comfort.

Table 2: Characteristics of service and PI pressure redistributing equipment use for interview participants

\begin{tabular}{|c|c|c|}
\hline \begin{tabular}{l|l} 
Participant & Regular service use
\end{tabular} & Recommended aids & Use of equipment \\
\hline
\end{tabular}




\begin{tabular}{|c|c|c|c|}
\hline 1 & $\begin{array}{l}\text { Community podiatry } 1 \mathrm{x} \\
\text { week. } \\
\text { Husband as main carer }\end{array}$ & None & $\mathrm{n} / \mathrm{a}$ \\
\hline 2 & $\begin{array}{l}\text { Carers } 1 \mathrm{x} \text { daily } \\
\text { Community podiatrist } 1 \mathrm{x} \\
\text { week } \\
\text { Family as main carers }\end{array}$ & $\begin{array}{l}\text { Hospital bed with dynamic } \\
\text { air mattress, } \\
\text { pressure redistributing } \\
\text { cushion for wheelchair, hoist }\end{array}$ & $\begin{array}{l}\text { Fully as } \\
\text { recommended }\end{array}$ \\
\hline 3 & $\begin{array}{l}\text { Community podiatrist } 1 \mathrm{x} \\
\text { fortnight } \\
\text { Partner as main carer }\end{array}$ & $\begin{array}{l}\text { None } \\
\text { Patient supplied own rising } \\
\text { recliner chair }\end{array}$ & $\mathrm{n} / \mathrm{a}$ \\
\hline 4 & $\begin{array}{l}\text { Carers } 2 \text { x daily } \\
\text { District nurses } 2 \text { x per week } \\
\text { Hospital podiatrist } 1 \text { x per } \\
\text { week }\end{array}$ & $\begin{array}{l}\text { Mattress overlay, pressure } \\
\text { redistributing cushion, heel } \\
\text { offloading device, boots, } \\
\text { cushion for feet in bed }\end{array}$ & $\begin{array}{l}\text { Partially as } \\
\text { recommended }\end{array}$ \\
\hline 5 & $\begin{array}{l}\text { Community podiatrist } 1 \mathrm{x} \\
\text { per week }\end{array}$ & Orthotic insoles & $\begin{array}{l}\text { Refused all } \\
\text { equipment }\end{array}$ \\
\hline 6 & $\begin{array}{l}\text { Carers } 3 \text { x daily } \\
\text { District nurses } 2 \text { x per week } \\
\text { Community podiatrist } 1 \mathrm{x} \\
\text { per week } \\
\text { Minimal caring from family }\end{array}$ & $\begin{array}{l}\text { Mattress overlay, pressure } \\
\text { redistributing cushion, } \\
\text { orthotic boots. } \\
\text { Supplement drinks. } \\
\text { Patient supplied own rising } \\
\text { recliner, chair and mobility } \\
\text { scooter. }\end{array}$ & $\begin{array}{l}\text { Partially as } \\
\text { recommended }\end{array}$ \\
\hline 7 & $\begin{array}{l}\text { Carers } 2 \times \text { daily } \\
\text { District nurses } 1 \times \text { daily } \\
\text { Husband and daughter help } \\
\text { with care }\end{array}$ & $\begin{array}{l}\text { Hospital bed with dynamic } \\
\text { air mattress, pressure } \\
\text { redistributing cushion, boot } \\
\text { (single). } \\
\text { Patient supplied own rising } \\
\text { recliner chair }\end{array}$ & $\begin{array}{l}\text { Fully as } \\
\text { recommended }\end{array}$ \\
\hline 8 & $\begin{array}{l}\text { Community podiatrist } 1 \mathrm{x} \\
\text { fortnight }\end{array}$ & None & $\mathrm{n} / \mathrm{a}$ \\
\hline 9 & $\begin{array}{l}\text { Carers } 3 \text { x daily } \\
\text { District nurses } 2 \text { x per week } \\
\text { Family help with care }\end{array}$ & $\begin{array}{l}\text { Hospital bed with dynamic } \\
\text { air mattress, pressure } \\
\text { redistributing cushion, } \\
\text { rising recliner chair, }\end{array}$ & $\begin{array}{l}\text { Fully as } \\
\text { recommended }\end{array}$ \\
\hline 10 & $\begin{array}{l}\text { Carers } 2 \text { x daily } \\
\text { District nurses } 1 \text { x per week } \\
\text { Family provide some care }\end{array}$ & $\begin{array}{l}\text { Hospital bed with dynamic } \\
\text { air mattress, } \\
\text { pressure redistributing } \\
\text { cushion, boots. } \\
\text { Patient supplied own rising } \\
\text { recliner chair }\end{array}$ & $\begin{array}{l}\text { Partially as } \\
\text { recommended }\end{array}$ \\
\hline 11 & Carers $4 \mathrm{x}$ daily & Hospital bed with dynamic & Fully as \\
\hline
\end{tabular}




\begin{tabular}{|l|l|l|l|}
\hline & $\begin{array}{l}\text { Hospital podiatry } 2 \times \text { per } \\
\text { week }\end{array}$ & $\begin{array}{l}\text { air mattress, powered } \\
\text { wheelchair with pressure } \\
\text { redistributing cushion, heel } \\
\text { off -loading device, hoist }\end{array}$ & recommended \\
\hline 12 & $\begin{array}{l}\text { Currently hospital inpatient. } \\
\text { Patient has carers 4 x daily at } \\
\text { home }\end{array}$ & $\begin{array}{l}\text { Hospital bed with dynamic } \\
\text { air mattress, wheelchair with } \\
\text { pressure redistributing } \\
\text { cushion }\end{array}$ & $\begin{array}{l}\text { Fully as } \\
\text { recommended }\end{array}$ \\
\hline
\end{tabular}

\section{The experience of service use}

The interview narratives revealed the experience of living with a PI was characterised by extensive hospital stays; followed by intensive community support that often involved hospital out-patient and outreach services, general practice, community nursing, community care services, and allied health and paramedic care. Patients generally reported high levels of service use (see table 2). Participants reported worry about continuity of care, and living with a reliance upon services. These are discussed in detail below.

\section{Worrying about continuity of care}

Participants were all in agreement that continuity of care, and the trust built from stable relationships with health professionals, was fundamental to their personal wellbeing and potential for recovery. Reflecting on the importance of carer familiarity with service providers, the long-term family carer of participant 2 recounted:

You know, that is the first thing I think, is to have the same continuity of care, you know, the same person all the time... I think that is so important, because it's that trust. You build up a trust, you've got the confidence. It's like [name of participant] can deal with any hospital appointment because she knows the person. But you put her in with someone different and she gets all flustered, you know, she's worried that 
she's going to make a mistake when they ask her a question. Whereas, once she gets to know them, she's quite confident (carer of participant 2).

Ultimately, participants believed that their quality of life and their ability to steward their personal healing process and protect against further pressure injury, was vastly improved when their care was delivered by clinicians and community carers familiar with their condition. The power of this continuity was captured in the further comment from participant 2 who stated, "If I could see just one person every time, my life would be completely different". Thus, continuity in service provision was framed as life changing. Its absence had a profound impact.

For those living with a PI, the worry that clinicians were not familiar with their condition, or did not have sufficient knowledge about their PI and its management, was an ongoing burden:

I've had nurses from three different towns this week. What worries me is they have never seen these legs before. They don't really know what they do about it. I don't mean they don't know what they're doing, but you know what I mean, they don't know what they're doing with these actual legs. They've never seen them before ... all these strange people these last two weeks they've never seen me before and you know I think it wants somebody that sees it more often. If you had, I know you can't have the same one all the time, but if you had two or three that came all the while it would be much better than having all the different ones coming in (participant 4).

Worry about service staff interrupting their care plan, or delivering inappropriate care due to a lack of continuity and familiarity with their care needs was a constant backdrop, which 
framed the experience of living with a PI. Recounting this experience, participant 4 described an occasion when community nurses arrived to attend to her care without the necessary equipment and supplies, meaning that the correct protocols could not be followed: "he [home visiting nurse] hadn't got any compressions [bandages]...he couldn't put the compression bandage on this leg which it's supposed to go on" (participant 4). Not receiving the correct care, was contrasted with the confidence and trust that came from receiving care from a familiar and experienced nurse:

I have great confidence in the tissue viability nurse and I just wish she could look at it every day and do the dressings but they are so limited and have so many people to see. It's not only bedsores they are doing but all wounds and they are run off their feet (participant 12).

\section{Living with a reliance upon services: Dependence, vigilance and vulnerability}

Among participants there was profound concern that their dependence upon services increased their vulnerability. Having already been exposed to risk and suffered considerable harm, patients and their family were vigilant to the ongoing risk of further harm. Thus, dependence, vulnerability and vigilance were inextricably linked in the experience of receiving PI care from community services. One participant reflected "I think it [danger of PI recurrence] will be there, very risky ... it worries me that you know it might happen" (participant 4).

As participants moved between hospital and at-home care, their sense of vulnerability and risk was heightened. During transition between services, patients were particularly vigilant to maintain the quality of their own care. Feelings of vulnerability and anxiety arose when participants' sensed communication issues between care providers, or when they perceived 
undermining of agreed treatment plans invoked whilst in hospital. Having had previous unsatisfactory experiences when moving between hospital and community care settings, participant 12 recounted how her vulnerability was exacerbated through the actions and statements of community nurses who disagreed with the care plan instituted by the tissue viability nurse:

They [nurses] come at any time...they come in say 'that's the wrong sort of dressing, that's not right'. I say 'hang on a minute, before you do anything, the tissue viability nurse said...', but they say 'well I think she's got that wrong I'll think we'll do something else'. That's the problem I have that the tissue viability nurse, who is the expert doing a wonderful job - you get home and the district nurse does something entirely different. So what I've said to the tissue viability nurse, when I go home will she please send me home with a very specific care plan. So I can actually go to the district nurse and say 'this is what is to happen'. The district nurse is lovely, but she felt that she knew more than the tissue viability nurse and that the dressing wasn't right. I suppose when you've got the specialist you know that she's done training to be perfect in her job, and she is the specialist full stop. I'll go with whatever she tells me and do whatever she tells me. But when someone comes and changes it all, you've immediately lost faith in the fact that you had a dressing on, from someone who knew exactly what she was doing... I think in the community, the liaison between the hospital tissue viability nurse, doesn't link up with the community (participant 12).

The nature and magnitude of patients' vulnerability was tightly coupled to a sense of dependence or lack of control over receiving care when needed. Though participants attempted to retain control over their own care plans, they were dependent upon care workers 
complying with their care plan, with care transgressions causing considerable discomfort and risk of further harm:

I think it's at risk of getting a sore again... I get uncomfortable and with these carers when they don't put the stuff right, like last night ... I've got a kylie (bed mat) underneath my pads so that if my wound did start leaking again at least I've got the protection. But, he (carer) put the kylie above the pads and all night it was irritating my back (participant 9)

Reliance upon community services was made more difficult for patients when they needed to make unplanned calls to their nursing team. This was not always straightforward, and patients were often left to deal with a third party: "you can't phone straight to your nurses any more, you have to go through this thing, a nurse answers then they get in touch with my nurse " (participant 9). For other participants, there was no sense of continuity or consistency when they were in need of unplanned care. Recalling an occasion when she experienced ooze from her pressure injury and couldn't get in touch with the nursing service, participant 4 stated:

I had to call 111 [emergency services] and I just told them. 'We'll send an ambulance' they said, I said 'no I don't want an ambulance, I just want somebody who will come and take all this off [dressing] and put some more on'. But no they couldn't find anyone, so then the paramedics came and all they said was we're not allowed to take it off. So I thought that's a lot of good (participant 4).

For other participants, making unplanned contact with health and nursing services was a last resort 'if it gets worse I could call them [nurses], to which I don't, I don't want to be a pain with calling, I don't want to be a bloody nuisance" (participant 6). 


\section{Discussion}

The findings presented in this paper highlight that people living with PI in their own homes utilise a range of pressure redistributing devices. In the tightly controlled hospital environment, PI equipment and aids are likely to be implemented in a predictable fashion. This contrasts with the unpredictability of the home environment. A striking finding from our study was that only one third of pressure-redistributing devices were used as recommended. These findings resonate with earlier qualitative studies of people living with PI (Hopkins et al., 2006) who reported painful discomfort from pressure-redistributing devices. Non-compliance with recommended equipment has previously been described by Thomas et al. (2010) regarding patients transitioning from hospital to home following hip replacement. From their in-depth literature search, the reasons for non-compliance enlighten the experiences of the interviewed participants in this study; patients not included in the decision process when choosing equipment, inadequate instructions given by health care professionals, improvement in the patient's medical condition to the point where the equipment was redundant, and proper evaluation of the patients individual circumstances at home such as living alone or having a spouse that can offer assistance in the place of equipment.

A further feature of participants' narratives highlighted that people living with PI often struggled to maintain continuity of their own care. This concurs with Guest et al. (2016) who described confusion and confliction with wound treatment plans when the dressing types were switched at successive wound dressing changes. In this study, those living with PI are in contact with health professionals for extended periods of time where health-related quality of life living with a PI was influenced by opportunities for dialogue and mutual decision making between patients and health professionals, with agreement about symptoms and 
treatment plans allowing patients to regain some control and independence (Gorecki et al., 2009).

To support people living with PI to engage as active partners in managing their health journey, what is required is a systems approach (Leyshon \& McAdam, 2015) and a deeper understanding of the linkages, relationships and patterns of risk that characterise the whole system of care. A particular challenge faced by people living with PI in the community was continuity of care between services and between care workers and health professionals. For participants, discharge from hospital was experienced as a time of heightened vulnerability, exacerbated by poor communication and changes to prescribed plans of care. Improvements to actively involve patients during the transition between services is warranted, as patients have a privileged and unique perspective on their own care needs and vulnerabilities (Vincent \& Amalberti, 2016). Information of PI prevention and management also needs to be readily and accessible to patients to support self-care (Hudgell et al., 2015).

Patient activation is a concept focused upon engagement, health literacy and selfmanagement capabilities, and recognises that improved outcomes are delivered when patients are active in their own care (Darzi, 2008). Patients who are more activated, are likely to engage more in positive health behaviours and improved chronic disease management, they are also less likely to be readmitted to hospital within thirty days of discharge (Hibbard \& Greene, 2013; Smith et al., 2013). Even though some participants in our study were motivated towards active involvement in their own PI management, this desire for activation was not actively supported or enabled, particularly during care transitions. Efforts to actively involve patients in their PI prevention and care are needed, including a more nuanced understanding of strategies to enable active patient involvement. The patient/health professional relationship is important when managing chronic illness, with a need for 
collaboration and partnership working to ensure optimal care is achieved (Jackson et al., 2016).

Pressure injury patients in the community generate significant human and economic costs through heavy use of health services and provision of pressure redistributing equipment. Poor communication, changes to prescribed plans of care and lack of patient input renders patients vulnerable and specialised equipment remains unused. Interventions that are acceptable to patients and can be incorporated into self-care strategies, including ongoing individualised assessment around the used of PI-associated equipment are needed.

\section{Conclusions}

To our knowledge, the use of equipment by PI patients has only been reported from the viewpoint of the healthcare provider and not the patient. International guidance advocates periodic re-evaluation of equipment, although this study shows this does not happen in practice. Efficacious use of pressure relieving equipment and devices includes regular assessment and reassessment, and engaging with patients on their decisions around altered or non-use of equipment. Patient education and individualised assessment around the use of pressure relieving equipment and devices are essential. In addition, collaborations to develop interventions and devices that support patients and are acceptable to patients are needed.

\section{References}

Asimus, M., \& Li, P. (2011). Pressure ulcers in home care settings: is it overlooked? Wound Practice \& Research: Journal of the Australian Wound Management Association, 19(2), 8897. 
Borbasi, S., \& Jackson, D. (2012). Navigating the maze of research. ( $3^{\text {rd }}$ ed.). Chatswood, Sydney: Mosby Elsevier.

Coleman, S., Gorecki, C., Nelson, E.A., Closs, S.J., Defloor, T., Halfens, R.,...Nixon, J. (2013). Patient risk factors for pressure ulcer development: systematic review. International Journal of Nursing Studies, 50(7), 974-1003.

Darzi, A. (2008). High quality care for all: NHS next stage review final report. London: The Stationary Office

Dealey, C., Posnett, J., \& Walker, A. (2012). The cost of pressure ulcers in the United Kingdom. Journal of Wound Care, 21(6), 261-266.

Fusch, P.I., \& Ness, L.R. (2015). Are we there yet? Data saturation in qualitative research. The Qualitative Report, 20(9), 1408-1416.

Gorecki, C., Brown, J.M., Nelson, E.A., Briggs, M., Schoonhoven, L., Dealey, C., ...Nixon, J. (2009). 'Impact of pressure ulcers on quality of life in older patients: a systematic review', Journal of the American Geriatrics Society, 57(7), 1175-1183.

Guest, J.F., Ayoub, N., McIlwraith, T., Uchegbu, I., Gerrish, A., Weidlich, D., ...Vowden, P. (2016). Health economic burden that different wound types impose on the UK's National Health Service. International Wound jJournal, 14, 322-330.

Heale, M. (2016). Patient repositioning strategies for pressure injury prevention. Retrieved from http://www.woundsource.com/blog/patient-repositioning-strategies-pressure-injuryprevention.

Hibbard, J.H., \& Greene, J. (2013). What the evidence shows about patient activation: better health outcomes and care experiences; fewer data on costs. Health Affairs, 32(2), 207-214.

Hopkins, A., Dealey, C., Bale, S., Defloor, T., \& Worboys, F. (2006). Patient stories of living with a pressure ulcer. Journal of Advanced Nursing, 56(4), 345-353.

Hughes, R. (Ed.). (2008). Patient safety and quality: An evidence-based handbook for nurses. Rockwell, MD: AHRQ Publication.

Hudgell, L., Dalphinis, J., Blunt, C., Zonouzi, M., \& Procter, S. (2015). Engaging patients in pressure ulcer prevention. Nursing Standard, 29(36), 64-70.

Jackson, D., Hutchinson, M., Barnason, S., Li, W., Mannix, J., Neville, S., ... Usher, K. (2016). Towards international consensus on patient harm: perspectives on pressure injury policy. Journal of Nursing Management, 24(7), 902-914. 
Jackson, D., Durrant, L., Bishop, E., Walthall, H., Betteridge, R., Gardner, S., ... Usher, K. (2017). Pain associated with pressure injury: A qualitative study of community-based, homedwelling individuals. Journal of Advanced Nursing. Advanced online publication. doi:10.111/jan.13370

Johansen, E., Bakken, L.N., \& Moore, Z.. (2015). Pressure ulcer in Norway - a snapshot of pressure ulcer occurrence across various care sites and recommendations for improved preventive care. Healthcare, 3(2), 417-428.

Landi, F., Onder, G., Russo, A. \& Bernabei, R. (2007). Pressure ulcer and mortality in frail elderly people living in community. Archives of Gerontology and Geriatrics, 44, 217-223.

Leyshon, S., \& McAdam, S. (2015). Scene setter: the importance of taking a systems approach to person centred care. British Medical Journal, 350, h985.

Moore, Z. \& Cowman, S. (2012). Pressure ulcer prevalence and prevention practices in care of the older person in the Republic of Ireland. Journal of Clinical Nursing, 21(3-4), 362-371.

Moore, Z. \& Price, P. (2004). Nurses' attitudes, behaviours and perceived barriers towards pressure ulcer prevention. Journal of Clinical Nursing, 13(8), 942-951.

NHS Stop the Pressure (2016). Helping to prevent pressure ulcers. Retrieved from http://nhs.stopthepressure.co.uk/.

Office for National Statistics (2011). National Records of Scotland ; Northern Ireland Statistics and Research Agency (2016): 2011 Census aggregate data. Retrieved from https://www.ons.gov.uk/census/2011census.

Skogestad, I. J., Martinsen, L., Børsting, T. E., Granheim, T. I., Ludvigsen, E. S., Gay, C. L. $\&$ Lerdal, A. (2017). Supplementing the Braden scale for pressure ulcer risk among medical inpatients: the contribution of self-reported symptoms and standard laboratory tests. Journal of Clinical Nursing, 26: 202-214.

Smith, S.G., Curtis, L.M., Wardle, J., von Wagner, C., \& Wolf, M.S. (2013). Skill set or mind set? Associations between health literacy, patient activation and health. PloS one, 8(9), e74373. http://dx.doi.org/10.1371/journal.pone.0074373

Smith, J.A., Flowers, P., Larkin, M. (2009). Interpretative phenomenological analysis: Theory, method and research. London: Sage.

Thomas, W.N., Pinkelman, L.A. \& Gardine, C.J. (2010). The reasons for non-compliance with adaptive equipment in patients returning home after a total hip replacement. Physical \& Occupational Therapy In Geriatrics, 28(2), 170-180. 
Vincent, C., \& Amalberti, R. (2016). Safer Healthcare: Strategies for the real world. London: Springer International Publishing.

Worsley, P.R., Smith, G., Schoonhoven, L., Bader, D.L. (2016). Characteristics of patients who are admitted with or acquire pressure ulcers in a district general hospital; a 3 year retrospective analysis. Nursing Open, 3(3), 152-158.

Yin, R.K., (1984). Case study research: Design and methods. Beverley Hills. 